Original Research Paper

\title{
Structural-Topological Synthesis of Planar Mechanisms with Rods and Wheels
}

\author{
${ }^{1}$ Nicolae Petrescu, ${ }^{2}$ Raffaella Aversa, ${ }^{2}$ Antonio Apicella and ${ }^{3}$ Relly Victoria V. Petrescu \\ ${ }^{1}$ Bucharest University, Bucharest, (CE), Romania \\ ${ }^{2}$ Department of Architecture and Industrial Design, \\ Advanced Material Lab, Second University of Naples, 81031 Aversa (CE), Italy \\ ${ }^{3}$ ARoTMM-IFToMM, Bucharest Polytechnic University, Bucharest, (CE), Romania
}

Article history

Received: 02-06-2018

Revised: 09-06-2018

Accepted: 19-06-2018

Corresponding Author: Relly Victoria V. Petrescu ARoTMM-IFToMM, Bucharest Polytechnic University, Bucharest, (CE), Romania E-mail: rvvpetrescu@gmail.com

\begin{abstract}
Today, robots are increasingly present in the machine building industry, sometimes even in some sections to replace workers altogether, due to the high quality of their work, repetitive, without stopping or pausing, without any manufacturing and assembly scuffs. Additionally, robots do not get sick, do not require medical leave or rest, work faster and better than humans and also support toxic environments from dyers, general assemblies, etc. Generally, robots have increased the quality and productivity of work and have not even created a union to defend their claims, demanding increased wages for them and larger holidays. Interestingly, a robot is working without a break, but without salary, without breaks, without complaining about working conditions in the plant. It has come to the effect that the big car manufacturers and even others, have entire sections in which only robots work. They do not have to worry about each other, do not quarrel, do not complain, do not cry, do not ask for the salary, do not require leave, they do not want free days and can work with high returns and Saturday and Sunday, if necessary on three shifts without a break. The importance of implementing robots can no longer be challenged. They have so increased the quality of work and the production of an enterprise that they can no longer give up their help. Workers have reclassified themselves and work only in more friendly workplaces, or in other workplaces, such as supermarkets, in better conditions, with higher wages, with several days off and they are also pleased and all this is due to production and additional gains from higher sales due to the robot work in large factories. We can clearly state that robots have improved our lives considerably. Thanks to them, a new free day was introduced for almost all working people, Friday, in addition to Saturday and we may soon be able to introduce another free day, but we have to choose whether it is Monday or Thursday. In this paper we present the mechanisms with bars and gears, which are planetary mechanisms for robot automation and mechatronics, structurally-topological. The gears and gears consist of at least one movable articulated bar and one of the cylindrical, tapered or hipoidal gears. Only gears with circular or straight toothed gears, in which the relative position of the rotation or translation axes does not change, shall be considered. The topological structure of the gears and gears is characterized by a kinematic chain with articulated bars and at least one kinematic chain with gears. The kinematic chain may be chain open (with a fixed rotation joint) or closed chain (with at least two fixed joints). The kinematic chain with gears is attached to the kinematic chain with bars so that at least two gear wheels have centers in the bars of the bars and some wheels may be integral with the bars. In practice, some of these gears with gears and gears are known as planetary gears with cylindrical, conical or hipoidal gears.
\end{abstract}

Keywords: Robots, Mechatronic Systems, Structure, Topology 


\section{Introduction}

Today, robots are increasingly present in the machine building industry, sometimes even in some sections to replace workers altogether, due to the high quality of their work, repetitive, without stopping or pausing, without any manufacturing and assembly scuffs.

Additionally, robots do not get sick, do not require medical leave or rest, work faster and better than humans and also support toxic environments from dyers, general assemblies, etc.

Generally, robots have increased the quality and productivity of work and have not even created a union to defend their claims, demanding increased wages for them and larger holidays. Interestingly, a robot is working without a break, but without salary, without breaks, without complaining about working conditions in the plant.

Robots can work on three shifts, that is, permanently, but not by shifting them like people did, but always remaining the same robots deployed in operation, nonstop, for days, without breaks, without rest, without problems.

It has come to the effect that the big car manufacturers and even others, have entire sections in which only robots work. They do not have to worry about each other, do not quarrel, do not complain, do not cry, do not ask for the salary, do not require leave, they do not want free days and can work with high returns and Saturday and Sunday, if necessary on three shifts without a break.

The importance of implementing robots can no longer be challenged. They have so increased the quality of work and the production of an enterprise that they can no longer give up their help. Workers have reclassified themselves and work only in more friendly workplaces, or in other workplaces, such as supermarkets, in better conditions, with higher wages, with several days off and they are also pleased and all this is due to production and additional gains from higher sales due to the robot work in large factories.

We can clearly state that robots have improved our lives considerably. Thanks to them, a new free day was introduced for almost all working people, Friday, in addition to Saturday and we may soon be able to introduce another free day, but we have to choose whether it is Monday or Thursday.

People, in the beginning, were taught by the trade union bosses to chase and sabotage the robots, to ruin them and not to accept them. Today things are clear and the robots work quietly in the big companies and factories for the sake of everyone, so now we can all accept the silence of the automation, the robotics, the electronics, without letting us be fooled by the union leaders, who slowly slow down and they will calm down.

If we like it or not like, robots have already stolen all our hard works places.
Anthropomorphic robots are, as I have already said, in most of the most widespread and widely used works worldwide today, due to their ability to adapt quickly to forced work, working without breaks or breaks $24 \mathrm{~h}$ a day, without unpaid leave without asking for food, water, air, or salary. Anthropomorphic robots are supple, elegant, easy to configure and adapted to almost any required location, being the most flexible, more useful, more penetrating, easy to deploy and maintain. For the first time, these robots have asserted themselves in the automotive industry and especially in the automotive industry, today they have penetrated almost all industrial fields, being easily adaptable, flexible, dynamic, resilient, cheaper than other models, occupying a volume smaller but with a major working space. They can also work in toxic or dangerous environments, so used in dyeing, chemical cleaners, in chemical or nuclear environments, where they handle explosive objects, or in military missions to land or sea mines, even if they were banned to use, because there are still countries around the globe that use them, such as Afghanistan.

The most used today's industrial robots, is built. The importance of the study of anthropomorphic robots has also been signaled, being today the most widespread robots worldwide, due to its simple design, construction, implementation, operation and maintenance. In addition, anthromomorphic systems are simpler from a technological and cheaper point of view, performing a continuous, demanding, repetitive work without any major maintenance problems. The basic module of these robots was also presented geometrically, cinematically, of the forces, of its total static balancing and of the forces that arise within or after balancing. In the present paper we want to highlight the dynamics of the already statically balanced total module. It has been presented in other works and studied matrix spatially, or more simply in a plan, but in this case, it is necessary to move from the working plane to the real space, or vice versa, passage that we will present in this study. In the basic plan module already presented in other geometric and cinematic works, we want to highlight some dynamic features such as static balancing, total balancing and determination of the strength of the module after balancing. Through a total static balancing, balancing the gravitational forces and moments generated by the forces of gravity is achieved, balancing the forces of inertia and the moments (couples) generated by the presence of inertial forces (not to be confused with the inertial moments of the mechanism, which appear separately from the other forces, being part of the inertial torsion of a mechanism and depending on both the inertial masses of the mechanism and its angular accelerations. Balancing the mechanism can be done through various methods. Partial balancing is achieved almost in all cases where the actuators (electric drive motors) are fitted with a mechanical reduction, a mechanical transmission, a 
sprocket, spiral gear, spool screw type. This results in a "forced" drive balancing from the transmission, which makes the operation of the assembly to be correct but rigid and with mechanical shocks. Such balancing is not possible when the actuators directly actuate the elements of the kinematic chain without using mechanical reducers (Antonescu and Petrescu, 1985; 1989; Antonescu et al., 1985a; 1985b; 1986; 1987; 1988; 1994; 1997; 2000a; 2000b; 2001; Aversa et al., 2017a; 2017b; 2017c; 2017d; 2017e; 2016a; 2016b; 2016c; 2016d; 2016e; 2016f; 2016g; 2016h; 2016i; 2016j; 2016k; 20161; 2016m; 2016n; 2016o; Berto et al., 2016a; 2016b; 2016c; 2016d; Cao et al., 2013; Dong et al., 2013; Comanescu, 2010; Franklin, 1930; He et al., 2013; Lee, 2013; Lin et al., 2013; Liu et al., 2013; Mirsayar et al., 2017; Padula and Perdereau, 2013; Perumaal and Jawahar, 2013; Petrescu, 2011; 2015a; 2015b; Petrescu and Petrescu, 1995a; 1995b; 1997a; 1997b; 1997c; 2000a; 2000b; 2002a; 2002b; 2003; 2005a; 2005b; $2005 \mathrm{c} ; 2005 \mathrm{~d} ; 2005 \mathrm{e} ; 2011 \mathrm{a} ; 2011 \mathrm{~b} ; 2012 \mathrm{a} ; 2012 \mathrm{~b}$; 2013a; 2013b; 2016a; 2016b; 2016c; Petrescu et al., 2009; 2016; 2017a; 2017b; 2017c; 2017d; 2017e; 2017f; $2017 \mathrm{~g} ; 2017 \mathrm{~h} ; 2017 \mathrm{i} ; 2017 \mathrm{j} ; 2017 \mathrm{k} ; 2017 \mathrm{l} ; 2017 \mathrm{~m}$; $2017 \mathrm{n} ; 2017 \mathrm{o} ; 2017 \mathrm{p} ; 2017 \mathrm{q} ; 2017 \mathrm{r} ; 2017 \mathrm{~s} ; 2017 \mathrm{t}$; $2017 \mathrm{u} ; 2017 \mathrm{v} ; 2017 \mathrm{w} ; 2017 \mathrm{x} ; 2017 \mathrm{y} ; 2017 \mathrm{z} ; 2017 \mathrm{aa}$; 2017ab; 2017ac; 2017ad; 2017ae; 2018a; 2018b; 2018c; 2018d; 2018e; 2018f; 2018g; 2018h; 2018i; 2018j; 2018k; 20181; 2018m; 2018n).

In this paper we present the mechanisms with bars and gears, which are planetary mechanisms for robot automation and mechatronics, structurally-topological.

\section{Materials and Methods}

The rods and gears consist of at least one movable articulated bar and one of the cylindrical, tapered or hipoidal gears. Only gears with circular or straight toothed gears, in which the relative position of the rotation or translation axes does not change, shall be considered. The topological structure of the gears and gears is characterized by a kinematic chain with articulated bars and at least one kinematic chain with gears. The kinematic chain may be chain open (with a fixed rotation joint) or closed chain (with at least two fixed joints). The kinematic chain with gears is attached to the kinematic chain with bars so that at least two gear wheels have centers in the bars of the bars and some wheels may be integral with the bars. In practice, some of these gears with gears and gears are known as planetary gears with cylindrical, conical or hipoidal gears.

The gearing of these gears in these complex mechanisms is carried out in the form of series, parallel, or both parallel-series trains.

The system is made according to the articulated plan cinematic chain, which can be made as an open or closed kinematic chain.

\section{Flat-Bellows and Gears with Open Kinematic Chain}

They are divided into elementary mechanisms (with a single articulated bar) and layered complex mechanisms with at least two articulated bars. The gears and gears of the first category are called planetary mechanisms, being used as planetary mechanical transmissions.

In turn, the elementary mechanisms are made with a central wheel with the fixed rotation axis (Fig. 1) and with two central wheels (Fig. 2), whose axes coincide with the fixed axis of the articulated bar.

Elementary mechanisms with a central wheel (Fig. 1) have a central wheel marked with a Fig. 1 and a satellite wheel 2 with the mobile shaft. The bar is numbered 3 and the joints are marked with letter $A_{0}$ (double joint) or A (simple joint).

The two wheels 1 and 2 form a cylindrical gear, which is external (Fig. 1a) or interior (Fig. 1b and 1c). Each toothed wheel is represented by the rolling circle, which in the kinematic schematics symbolizes a continuous line.

The mobility of this gear with bars and gears is equal to 2 , which is deduced from the structural-numerical formula (1):

$$
M=\sum_{m=1}^{5}\left(m \cdot C_{m}\right)-\sum_{r=2}^{6}\left(r \cdot N_{r}\right)
$$

In formula (1) the following notations were used:

- Is the functional class of the kinematic couple (degree of freedom)

- Is the number of kinematic couplings of class $m$

- Is the rank of the space associated with a closed cinematic contour

- Is the number of closed kinematic contours independent of $r$

The total number $N_{c}$ of the closed contours is calculated using formula (2):

$$
N_{c}=\sum_{m=1}^{5} C_{m}-n
$$

In the formula (2), the total number of moving kinematic elements in the mechanism is denoted by $n$.

In the case of elementary gears with bars and gears (Fig. 1), the kinematic elements are in the form of a bar and a gear wheel and the kinematic couplers are rotation $(m=1)$, represented by plane and roto-translational joints $(m=2)$, represented by cylindrical gears.

Following the kinematic schemes (Fig. 1) the following numerical values are identified (3):

$m=1, C_{1}=3 ; m=2, C_{2}=1$
$r=3, n=3, N_{3}=1$ 
With these numerical values introduced in the formula (1) the expression (4) is obtained:

$$
M=(1 \cdot 5+2 \cdot 1)-3.1=2
$$

By immobilizing the crank wheel, the mechanism will have $M=1$ mobility, in which case the bar 3 may be a driving member and the toothed wheel 2 will become a driven member.

In this case, a point on the wheel 2 will describe an epicicloid curve (Fig. 1a), a hypo-cycloid (Fig. 1b) or a pericicloid (Fig. 1c).

The central two-gear center gears (Fig. 2) are obtained from the previous ones by the addition of a gear wheel 4 which engages the wheel 2' integral with 2 .

Since a toothed wheel is structurally topological equivalent to a diadem cinematic chain, the mobility of the new mechanisms (Fig. 2) is preserved, so $M=2$.

The mobility value is calculated by the formula (1) in which the numerical values specific to this two-wheel center mechanism (5) are introduced:

$$
m=1, C_{1}=4 ; m=2, C_{2}=2 ; r=3, n=4, N_{3}=2
$$

Thus, the mobility of the elementary mechanisms presented above results (6):

$M=(1 \cdot 4+2 \cdot 2)-3 \cdot 2=2$
The two cylindrical gears are both external (Fig. 2a), one inner and the other outside (Fig. 2b) or both interiors (Fig. 2c).

When installing the second central wheel 4 , account is taken of the geometric condition that the distance between the axes of the two gears is the same (7):

$m_{12} \cdot\left(z_{1} \pm z_{2}\right)=m_{2^{\prime} 4} \cdot\left(z_{2^{\prime}} \pm z_{4}\right)$

Complex gears with stacked bars and toothed wheels are obtained by overlaying the elementary mechanisms previously analyzed.

Overlaying refers to the kinematic chain with bars, which can have two bars (Fig. 3a) or several bars (Fig. 3b).

In the kinematic analysis of the two-bar mechanism (Fig. 3a), it should be noted that the wheel 3 is integral with the $A_{0} A$ bar and the wheel 2 is integral with the bar $\mathrm{AB}$. These solidarizations are highlighted in both projections, both in the axial plane and in the transverse projection, corresponding to the plane of the gears and gears.

There are four outer cylindrical gears, two at each level, which requires verification of the following deduced relationships from the equal distance between axes (8-9):

$m_{12} \cdot\left(z_{1}+z_{2}\right)=m_{45} \cdot\left(z_{4}+z_{5}\right)$

$m_{56} \cdot\left(z_{5}+z_{6}\right)=m_{36^{\prime}} \cdot\left(z_{3}+z_{6^{\prime}}\right)$

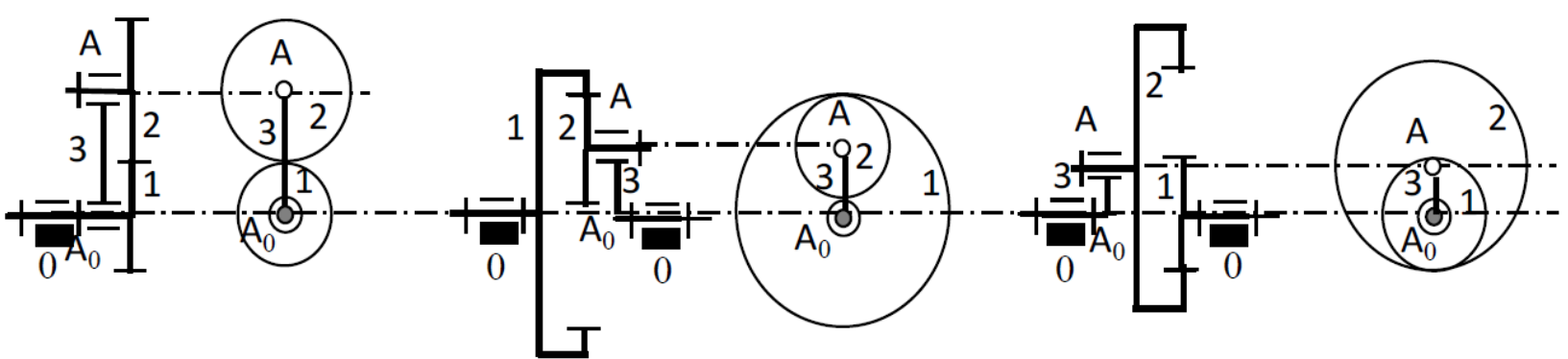

(a)

(b)

(c)

Fig. 1: The elementary mechanisms are made with a central wheel with fixed rotation axis

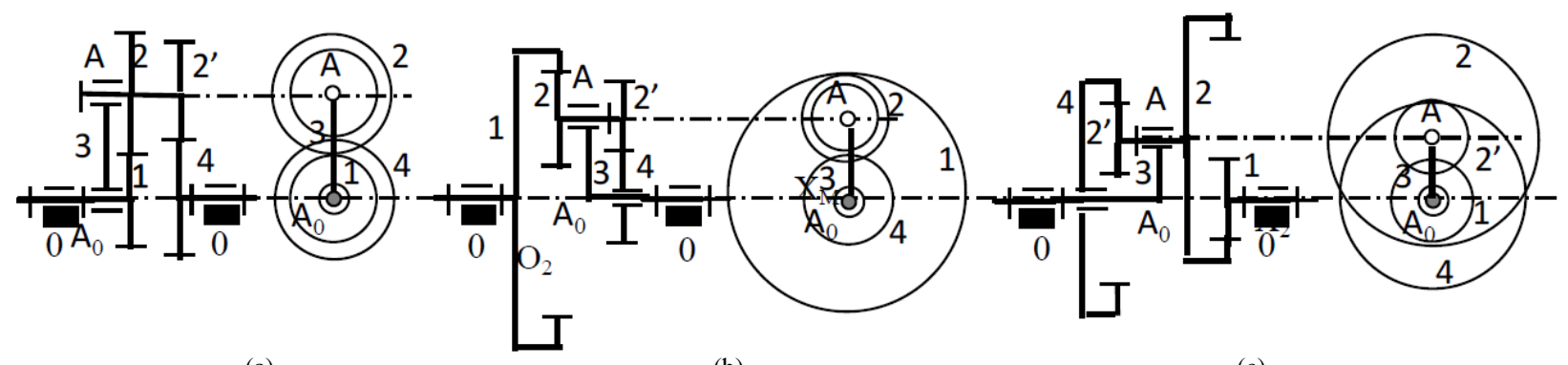

(a)

(b)

(c)

Fig. 2: The elementary mechanisms are made with two central wheels 


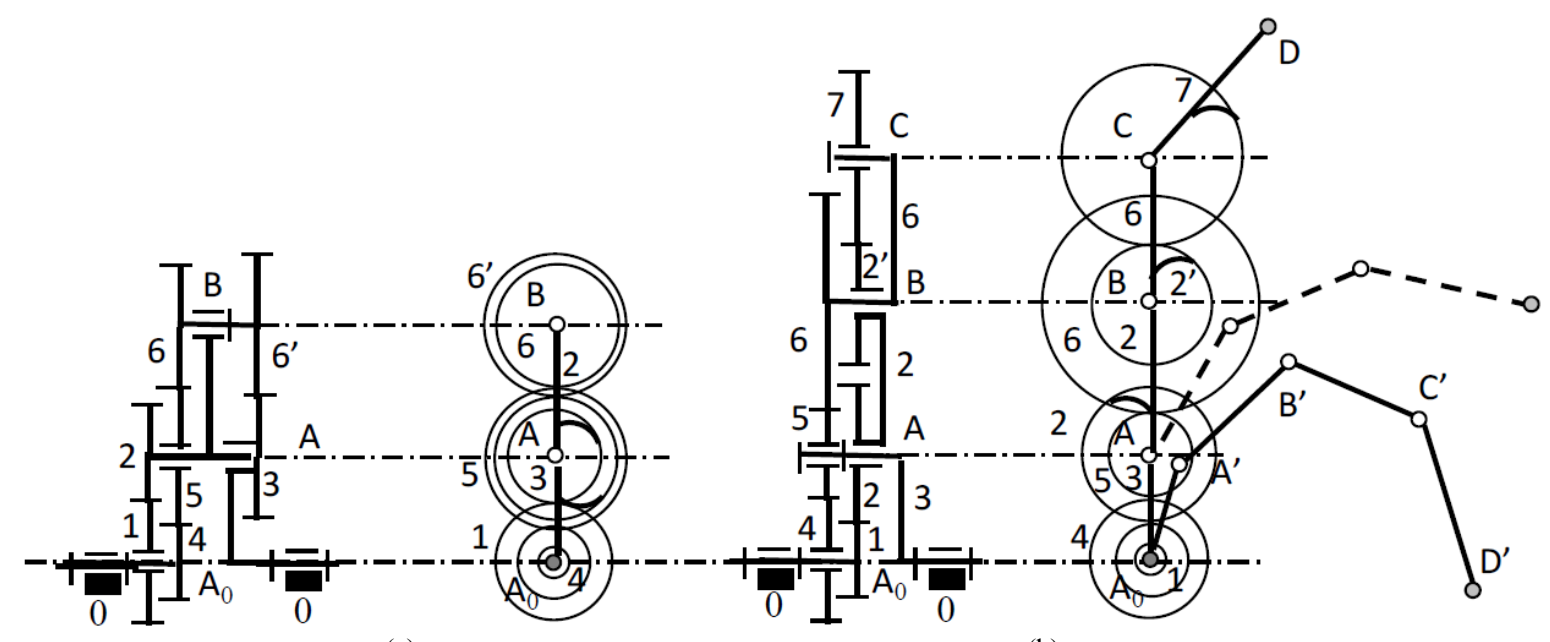

(a)

(b)

Fig. 3: Overlaying refers to the kinematic chain with bars, which can have two bars (Figure 3a) or several bars (Figure 3b)

The mobility of the simple flatbed mechanism (Fig. 3a) is $M=2$, this being calculated by means of formula (1), in which purpose the specific numerical values are determined (10):

$$
\begin{aligned}
& m=1, C_{1}=6 ; m=2, C_{2}=4 ; \\
& r=3, n=6, N_{3}=4 .
\end{aligned}
$$

With these data entered in the formula (1) the relationship (11) results:

$$
M=(1 \cdot 6+2 \cdot 4)-3 \cdot 4=2
$$

The composite block mechanism (Fig. 3b) is composed of the A0ABCD open-kinematic kinematic chain (in which the last CD is integral with the toothed wheel 7) and the kinematic chain with gears located in planes parallel to the main chain.

It is noted that the gears 2 and $2^{\prime}$ are integral with the bar $\mathrm{AB}$ and the toothed wheel 6 is integral with the articulated link bar BC.

For the first two cylindrical gears, mounted in parallel to the zero level, there is the relation (8), taking into account the notations identical to those in the kinematic scheme analyzed above.

The mobility of the overlayed mechanism (Fig. 3b) is $M=3$, which is verified using formula (12):

$$
M=(1 \cdot 7+2 \cdot 4)-3 \cdot 4=3
$$

In formula (12) the following numerical values specific to the analyzed mechanism (13) were introduced:

$$
\begin{aligned}
& m=1, C_{1}=7 ; \quad m=2, C_{2}=4 ; \\
& r=3, n=7, \quad N_{3}=4
\end{aligned}
$$

The geometric structure of this complex mechanism (Fig. 3b) corresponds to a redundant planar manipulator with three mobilities, at which point D can reach D' on a given trajectory.

\section{Results}

\section{Straight Mechanism with Flat Bars and Gears}

These planar mechanisms have, as a main chain with bars, a kinematic contour of the articulated quadrilateral, articulated pentalator, articulated hexalator, etc. The kinematic chain with toothed wheels is attached to the bar chain by positioning each circular wheel with the center in a polygonal contour joint.

The chain mechanism with quadrilateral bars is made with two, three or four gears, these being distinct kinematic elements or being solidly mounted with certain bars of the closed kinematic contour. In some situations, toothed wheels are also used with the centers placed at certain points on the bars, other than their joints.

Where appropriate, the articulated quadrilateral is crank-type, double crank and double swing (with simple and complex variants).

The kinematic chain with the crankshaft (Fig. 4) is further considered to be attached to the kinematic chain with two, three or four gears, respectively one, two or three cylindrical outer or inner gears.

Assuming that the mobility of the complex gear with bars and toothed wheels is $M=1$, one of the gears of the gears attached solidarizes with one of the articulated bars 1, 2 or 3 .

Variant 1 (Fig. 4a) is obtained when wheel 2 is integral with rod 2 of length $\mathrm{AB}=12$ and gear wheel 4 has a fixed rotation axis in $\mathrm{B} 0$ being a driven wheel.

Because the toothed wheel 4 is a distinct kinematic element, equivalent to a zero mobility chain diadem, by 
adding it to the articulated quadrant $(0,1,2,3)$ and $\mathrm{A}_{0} \mathrm{ABB}_{0}$ respectively, the mechanism mobility is preserved.

For verification, mobility is calculated with the general formula (1), where the numerical values specific to this complex mechanism are introduced (Fig. 4a), (14-15):

$m=1, \quad C_{1}=5 ; \quad m=2, C_{2}=1$
$r=3, n=4, N_{3}=2$

$M=(1 \cdot 5+2 \cdot 1)-3 \cdot 2=1$

The distance between the axes of the two gear wheels 2 and 4 of the external cylindrical gear that is mounted on the rocker 3 , of length $B_{0} B=13$, must fulfill the geometric condition (16):

$a_{24}=B B_{0}=\frac{1}{2} m_{24} \cdot\left(z_{2}+z_{4}\right)$

Variant 2 (Fig. 4b) has two cylindrical gears mounted on bars 2 and 3 , where wheel 1 with center in $A$ is integral with crank 1 of length $\mathrm{A}_{0} \mathrm{~A}=11$ and wheels 4 (4') and 5 are elements distinct cinemas, having centers in B and B0 respectively. The two toothed wheels 4 (4') and 5 are equivalent to two diadic chains, which preserve the mobility of the quadrilateral mechanism $\mathrm{M}=1$.

Variant 3 (Fig. 4c) comprises three cylindrical gears mounted on bars 1, 2 and 3, wherein the toothed wheel 0 with the center in $A_{0}$ is integral with the base of the quadrilateral. Wheels $4\left(4^{\prime}\right), 5\left(5^{\prime}\right)$ and 6 are distinct elements which equate to three diadic chains, so that $M=$ 1 mobility is preserved.

Chain mechanisms with pentalaters can be made with one or more cylindrical gears attached to the articulated pedal (Figure 5), in which, in order to obtain the mobility one $(\mathrm{M}=1)$, two conditions are introduced which aim at the solidarity of two wheels toothbrushes with distinct bars.

It is noted that from each of the above-mentioned variants, by attaching another rod of the articulated pentatal there are obtained two other variants of gears and gears, which means 9 distinct variants.

Variant 1 (Fig. 5a) is obtained by using two toothed wheels (with teeth numbers $z_{3}$ and $z_{0}$ ) having the centers in the $\mathrm{C}$ and $\mathrm{C}$ joints of the bar 4 and solidarized by the movable bar 3 and the fixed 0 respectively.

In this way the engagement of the two wheels is equivalent to the introduction of an additional link between bars 3 and 0 , which is equivalent to a bar and two articulations whose mobility is -1 .

The mobility of the resultant mechanism (Fig. 5a) is that of the articulated pentatal $(M=2)$, to which is added the mobility of the inserted engagement connection $(-1)$, i.e., $M=2-1=1$.
The same result is obtained by computing the mobility of the complex mechanism with the structural topological formula (2.1), whose particular form is (17):

$M=C_{1}+2 C_{2}-3 N_{3}=5+2 \cdot 1-3 \cdot 2=1$

The mounting condition of the two toothed wheels (Fig. 5a) is (18):

$a_{30}=C C_{0}=\frac{1}{2} m_{30} \cdot\left(z_{3}+z_{0}\right)$

If the bar 1 is a leading element, the complex mechanism is of Class 3, which can be determined by highlighting the triad once the upper coupling coupler is replaced by a binary bar (with two joints).

Following the two other kinematic schemes obtained from variant 1 (Fig. 5a and 6a) by changing the base, they each represent a complex mechanism of class 2 (Fig. 6b) and a complex class 4 mechanism (Fig. 6c).

Variant 2 (Fig. 5b) is obtained from the bi-mobile articulated catenary chain by attaching the toothed wheel chain with two cylindrical gears mounted on the bars 3 and 4 . Between the wheels with the centers in the joints $B$ and $C_{0}$ (integral with the bars 2 and 0 ) finds the toothed wheel $5\left(5^{\prime}\right)$ with the center in $C$, which is a distinct cinematic element.

The mobility of the complex mechanism is calculated by the formula (1), (19):

$M=C_{1}+2 C_{2}-3 N_{3}=6+2 \cdot 1-3 \cdot 3=1$

where, the following replacements were made (20):

$m=1, C_{1}=6 ; \quad m=2, C_{2}=2 ;$

$r=3, \quad n=5, \quad N_{3}=3$

The mounting conditions of the two cylindrical gears are (Fig. 5b; 21-22):

$$
\begin{aligned}
& a_{25}=B C=\frac{1}{2} m_{25} \cdot\left(z_{2}+z_{5}\right) \\
& a_{05^{\prime}}=C_{0} C=\frac{1}{2} m_{05^{\prime}} \cdot\left(z_{0}+z_{5^{\prime}}\right)
\end{aligned}
$$

And from this kinematic scheme (Fig. 5b and 7a) of class 4, two other distinct kinematic schemes are obtained, by changing the base, one of class 3 (Fig. 7b) and the other of class 4 (Fig. 7c).

Variant 3 (Fig. 5c) results from the bimobal pentalater chain by the attachment of a kinematic chain of gears with three cylindrical gears mounted on the bars 2, 3 and 4 . 
The gears with the centers in the joints $A$ and $C_{0}$ are integral with the bars 1 and 0 respectively and the gears $5\left(5^{\prime}\right)$ and $6\left(6^{\prime}\right)$ with the centers in the joints $B$ and $C$ are distinct kinematic elements.
Mobility is $M=1$, which is verified using formula ( 1 ; 23):

$$
M=C_{1}+2 C_{2}-3 N_{3}=7+2 \cdot 3-3 \cdot 4=1
$$

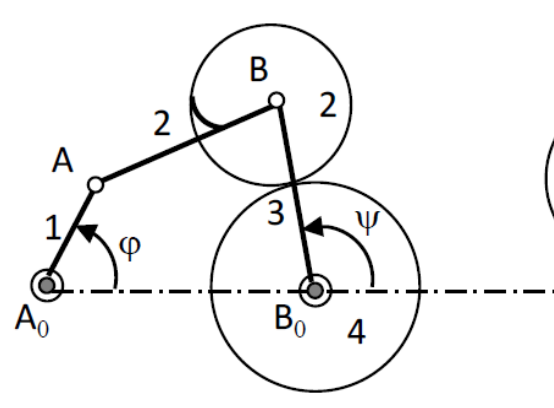

(a)

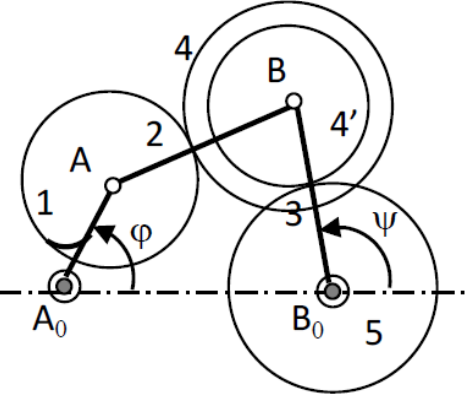

(b)

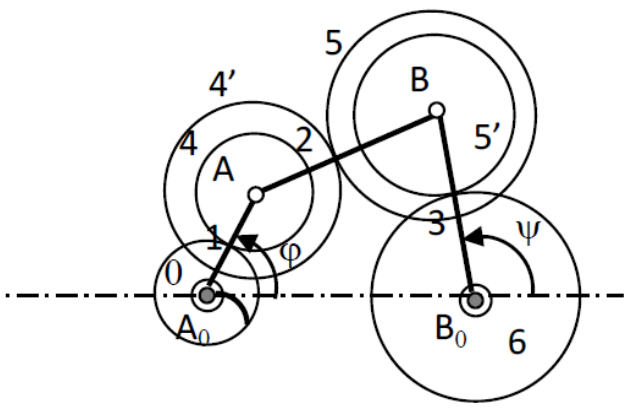

(c)

Fig. 4: The kinematic chain with the crankshaft (Fig. 4) is further considered to be attached to the kinematic chain with two, three or four gears, respectively one, two or three cylindrical outer or inner gears

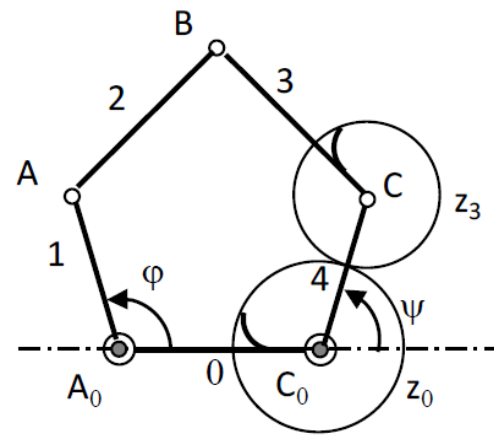

(a)

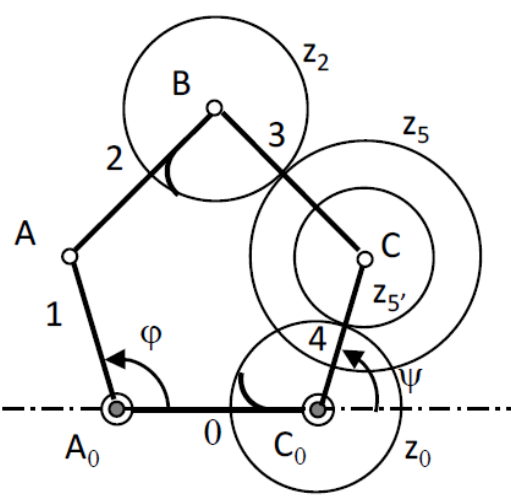

(b)

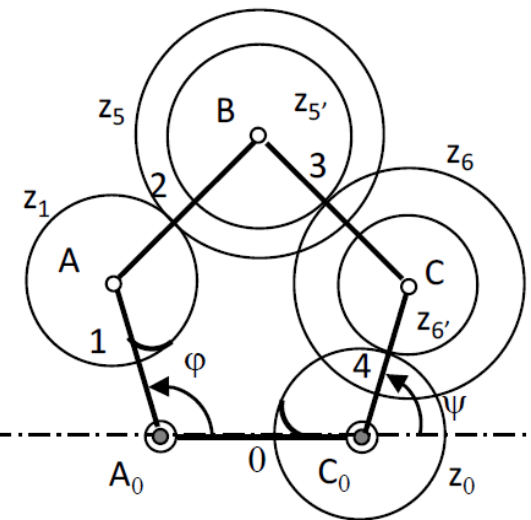

(c)

Fig. 5: Chain mechanisms with pentalaters can be made with one or more cylindrical gears attached to the articulated pedal, in which, in order to obtain the mobility one $(M=1)$, two conditions are introduced which aim at the solidarity of two wheels toothbrushes with distinct bars

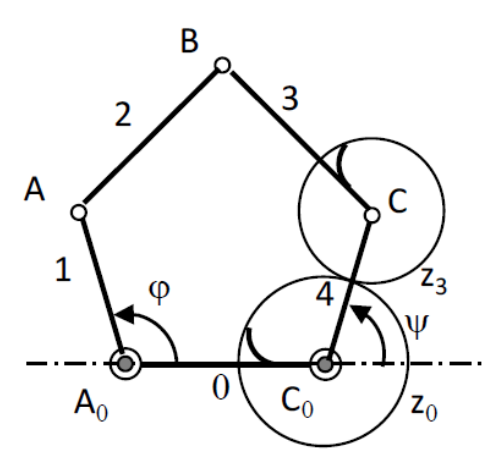

(a)

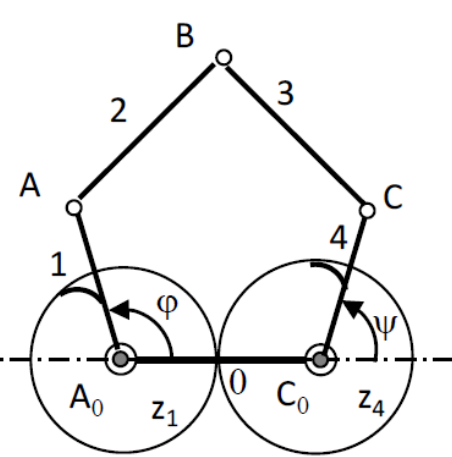

(b)

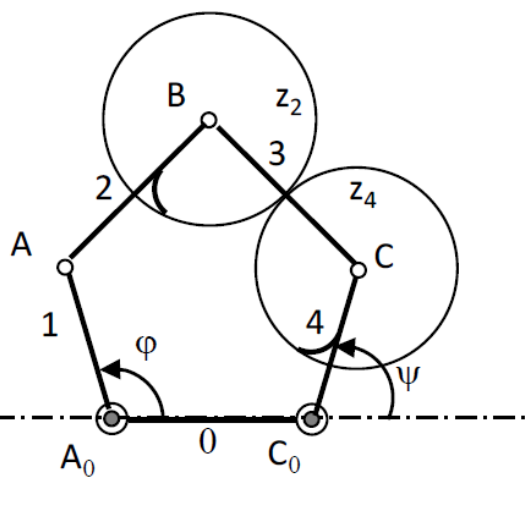

(c)

Fig. 6: Following the two other kinematic schemes obtained from variant 1 (Fig. 5a and 6a) by changing the base, they each represent a complex mechanism of class 2 (Fig. 6b) and a complex class 4 mechanism (Fig. 6c) 


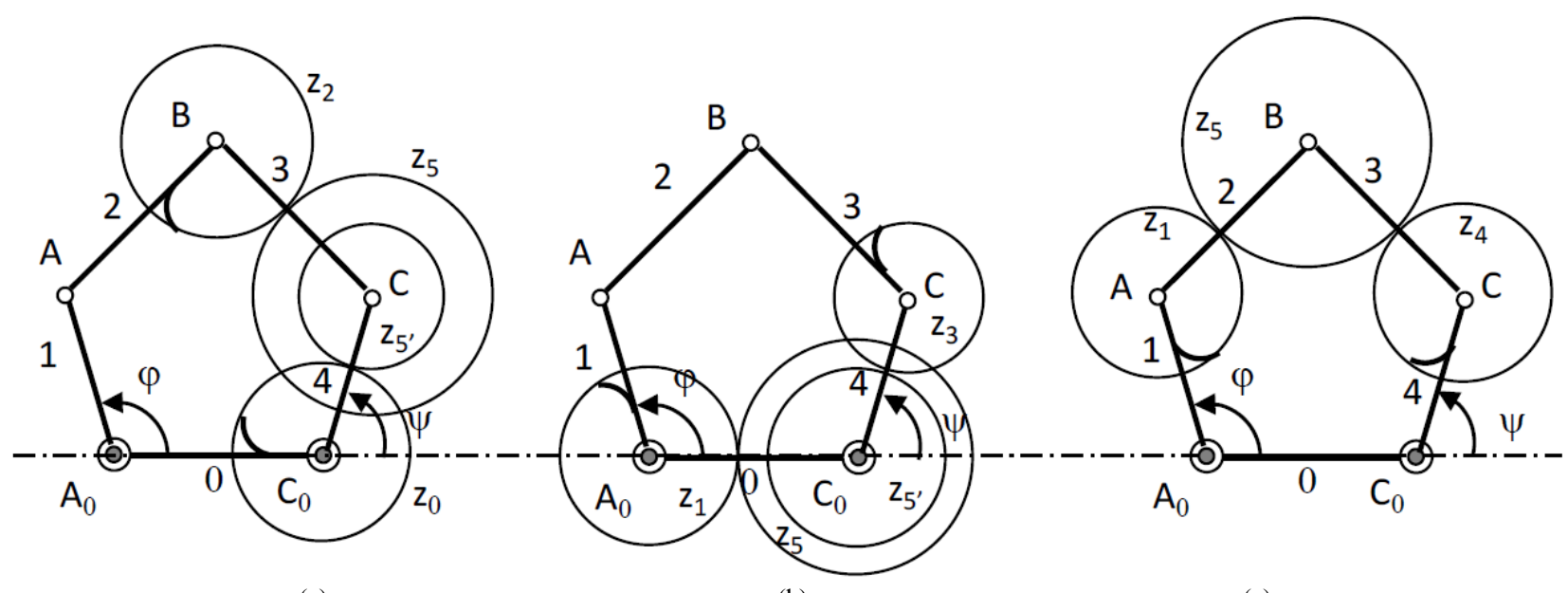

(a)

(b)

(c)

Fig. 7: From this kinematic scheme (Fig. $5 b$ and 7a) of class 4, two other distinct kinematic schemes are obtained, by changing the base, one of class 3 (Fig. 7b) and the other of class 4 (Fig. 7c)

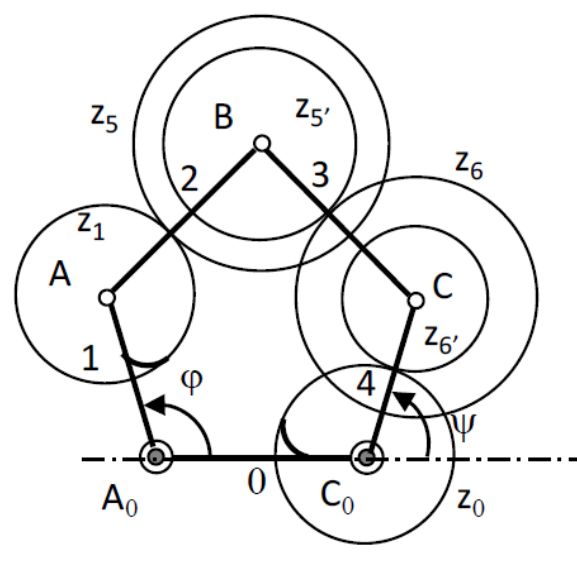

(a)

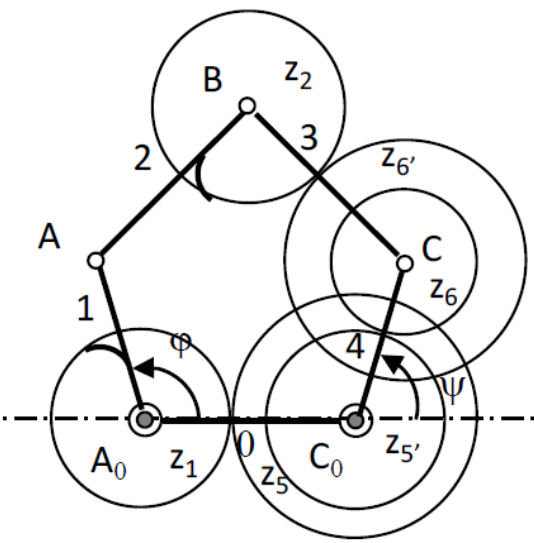

(b)

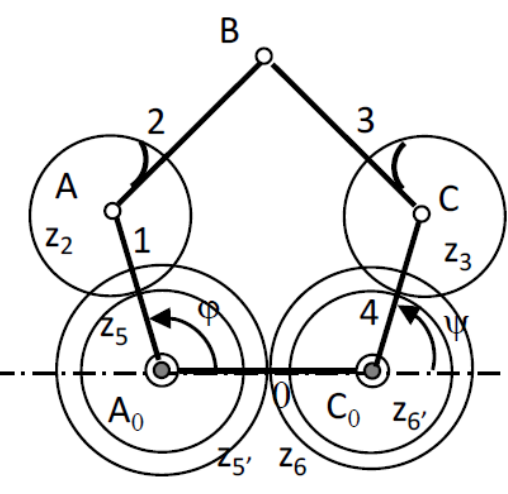

(c)

Fig. 8: From this kinematic scheme (Fig. $5 \mathrm{c}$ and $8 \mathrm{a}$ ) of class 4 ord. 4 , two other kinematic schemes are obtained by changing the base, one by one. 4 ord. 3 (Fig. 8b) and the other one. 7 ord. 4 (Fig. 8c)

From this kinematic scheme (Fig. 5c and 8a) of class 4 ord. 4, two other kinematic schemes are obtained by changing the base, one by one. 4 ord. 3 (Fig. $8 \mathrm{~b}$ ) and the other one. 7 ord. 4 (Fig. 8c).

The hexal-type chaining mechanisms are obtained by attaching a chain of gears with two or more gears to an articulated hexalator (Fig. 9), in which, in order to achieve a unitary mobility $(M=1)$, at least four wheels are solidarized with the bars.

Three kinematic schemes of such complex gears with bars and gears, each having two cylindrical gears, were considered (Fig. 9).

If equal gears are used, the first and third kinematic schemes (Fig. 9a and 9c) show a geometric symmetry, in which case the bar 3 performs a rectilinear translation motion.
Moreover, under the above-mentioned conditions and with the second kinematic scheme (Fig. 9b), the rectilinear translation of the rod 3 is obtained, even if the topological structure is not symmetrical.

The mobility of these complex mechanisms is $M=1$, which is verified by the calculation of formula $(1 ; 24)$ :

$M=C_{1}+2 C_{2}-3 N_{3}=6+2 \cdot 2-3 \cdot 3=1$

\section{Chain Mechanisms with Hexagonal and Octagonal Bars}

For these mechanisms there is an example of a kinematic scheme with a symmetrical geometric structure (Fig. 10). 


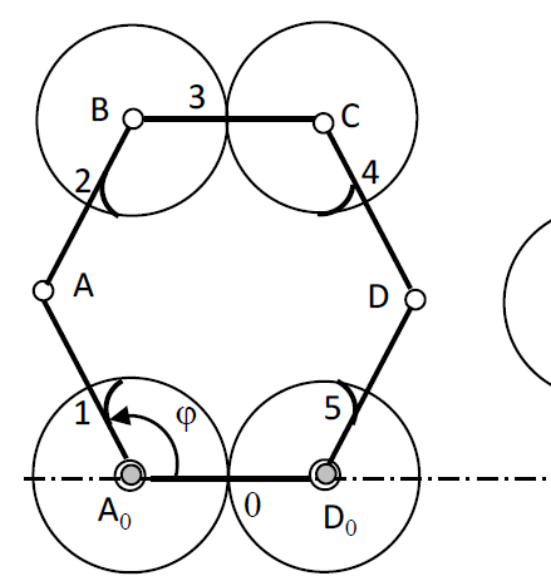

(a)

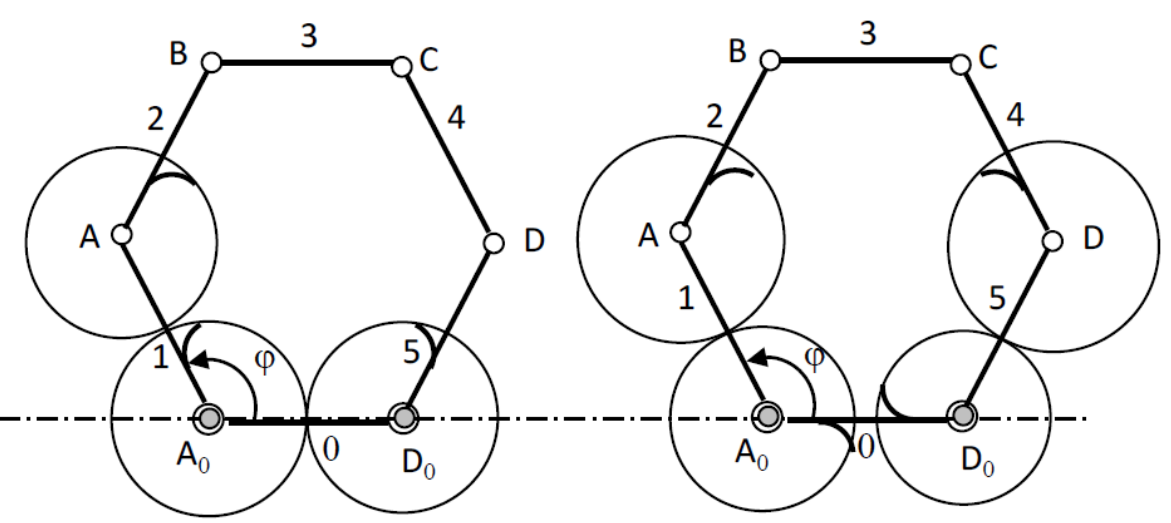

(b)

(c)

Fig. 9: The hexal-type chaining mechanisms are obtained by attaching a chain of gears with two or more gears to an articulated hexalator (Fig. 9), in which, in order to achieve a unitary mobility $(M=1)$, at least four wheels are solidarized with the bars. Three kinematic schemes of such complex gears with bars and gears, each having two cylindrical gears, were considered (Fig. 9). If equal gears are used, the first and third kinematic schemes (Fig 9a and 9c) show a geometric symmetry, in which case the bar 3 performs a rectilinear translation motion. Moreover, under the above-mentioned conditions and with the second kinematic scheme (Fig. 9b), the rectilinear translation of the rod 3 is obtained, even if the topological structure is not symmetrical

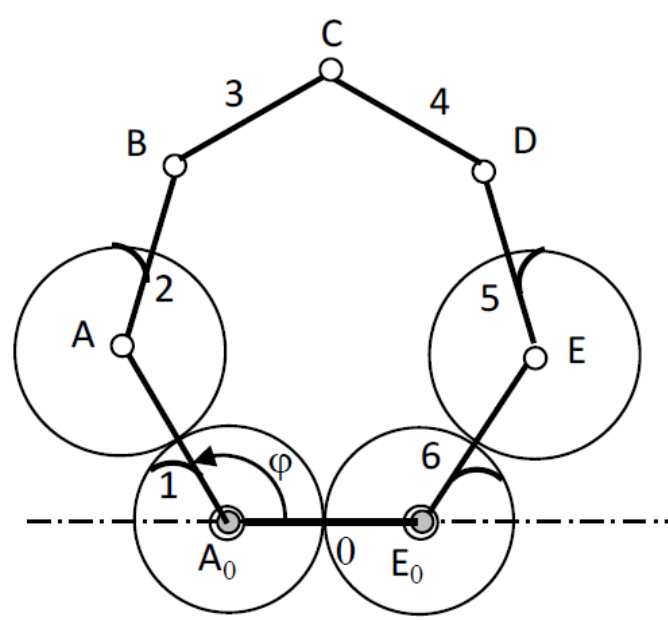

(a)

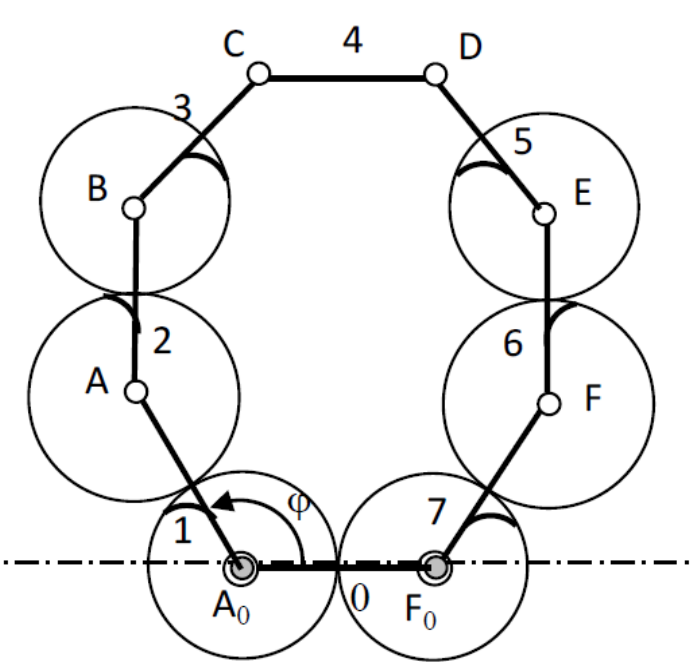

(b)

Fig. 10: The complex heptagonal chain mechanism (Fig. 10a) is made with three gears, one with fixed axes $(1,6)$ and two with movable axes $(1,2)$ and $(5,6)$. The octagonal chain complex mechanism (Fig. 10b) consists of five gears mounted symmetrically to the vertical symmetry axis of the octagon. Both mechanisms have mobility one $M=1$.

The complex heptagonal chain mechanism (Fig. 10a) is made with three gears, one with fixed axes $(1,6)$ and two with movable axes $(1,2)$ and $(5,6)$.

The octagonal chain complex mechanism (Fig. 10b) consists of five gears mounted symmetrically to the vertical symmetry axis of the octagon. Both mechanisms have mobility one $\mathrm{M}=1$.

For planar mechanisms of this kind we will stop at this point and in another paper we present the topology of the spatial mechanisms with bars and gears, which is much more complex than the similar planes already presented.

Next, all figures based on the previous chapter, already announced in this chapter, Fig. 4-10 will be shown.

\section{Discussion}

The rods and gears consist of at least one movable articulated bar and one of the cylindrical, tapered or hipoidal gears. Only gears with circular or straight toothed 
gears, in which the relative position of the rotation or translation axes does not change, shall be considered. The topological structure of the gears and gears is characterized by a kinematic chain with articulated bars and at least one kinematic chain with gears. The kinematic chain may be chain open (with a fixed rotation joint) or closed chain (with at least two fixed joints). The kinematic chain with gears is attached to the kinematic chain with bars so that at least two gear wheels have centers in the bars of the bars and some wheels may be integral with the bars. In practice, some of these gears with gears and gears are known as planetary gears with cylindrical, conical or hipoidal gears.

The gearing of these gears in these complex mechanisms is carried out in the form of series, parallel, or both parallel-series trains.

The system is made according to the articulated plan cinematic chain, which can be made as an open or closed kinematic chain.

Flat-bellows and gears with open kinematic chain are divided into elementary mechanisms (with a single articulated bar) and layered complex mechanisms with at least two articulated bars. The gears and gears of the first category are called planetary mechanisms, being used as planetary mechanical transmissions.

In turn, the elementary mechanisms are made with a central wheel with the fixed rotation axis (Fig. 1) and with two central wheels (Fig. 2), whose axes coincide with the fixed axis of the articulated bar.

Elementary mechanisms with a central wheel (Fig. 1) have a central wheel marked with a Fig. 1 and a satellite wheel 2 with the mobile shaft. The bar is numbered 3 and the joints are marked with letter A0 (double joint) or A (simple joint).

The two wheels 1 and 2 form a cylindrical gear, which is external (Fig. 1a) or interior (Fig. 1b and 1c). Each toothed wheel is represented by the rolling circle, which in the kinematic schematics symbolizes a continuous line.

The mobility of this gear with bars and gears is equal to 2 , which is deduced from the structural-numerical formula (1). By immobilizing the crank wheel, the mechanism will have $M=1$ mobility, in which case the bar 3 may be a driving member and the toothed wheel 2 will become a driven member.

In this case, a point on the wheel 2 will describe an epicicloid curve (Fig. 1a), a hypo-cycloid (Fig. 1b) or a pericicloid (Fig. 1c).

The central two-gear center gears (Fig. 2) are obtained from the previous ones by the addition of a gear wheel 4 which engages the wheel 2' integral with 2.

Since a toothed wheel is structurally topological equivalent to a diadem cinematic chain, the mobility of the new mechanisms (Fig. 2) is preserved, so $M=2$.
The mobility value is calculated by the formula (1) in which the numerical values specific to this two-wheel center mechanism (5) are introduced.

Complex gears with stacked bars and toothed wheels are obtained by overlaying the elementary mechanisms previously analyzed.

Overlaying refers to the kinematic chain with bars, which can have two bars (Figure 3a) or several bars (Figure 3b).

In the kinematic analysis of the two-bar mechanism (Figure 3a), it should be noted that the wheel 3 is integral with the A0A bar and the wheel 2 is integral with the bar AB. These solidarizations are highlighted in both projections, both in the axial plane and in the transverse projection, corresponding to the plane of the gears and gears.

There are four outer cylindrical gears, two at each level, which requires verification of the following deduced relationships from the equal distance between axes (8-9).

The composite block mechanism (Fig. 3b) is composed of the A0ABCD open-kinematic kinematic chain (in which the last $C D$ is integral with the toothed wheel 7) and the kinematic chain with gears located in planes parallel to the main chain.

It is noted that the gears 2 and 2 ' are integral with the bar $\mathrm{AB}$ and the toothed wheel 6 is integral with the articulated link bar BC.

For the first two cylindrical gears, mounted in parallel to the zero level, there is the relation (8), taking into account the notations identical to those in the kinematic scheme analyzed above.

The mobility of the overlayed mechanism (Fig. 3b) is $M=3$, which is verified using formula (12).

These planar mechanisms have, as the main chain with bars, a kinematic contour of the articulated quadrilateral, articulated pentalater, articulated hexalator, etc. The kinematic chain with toothed wheels is attached to the bar chain by positioning each circular wheel with the center in a polygonal contour joint.

The chain mechanism with quadrilateral bars is made with two, three or four gears, these being distinct kinematic elements or being solidly mounted with certain bars of the closed kinematic contour. In some situations, toothed wheels are also used with the centers placed at certain points on the bars, other than their joints.

Where appropriate, the articulated quadrilateral is crank-type, double crank and double swing (with simple and complex variants).

The kinematic chain with the crankshaft (Fig. 4) is further considered to be attached to the kinematic chain with two, three or four gears, respectively one, two or three cylindrical outer or inner gears.

Assuming that the mobility of the complex gear with bars and toothed wheels is $M=1$, one of the 
gears of the gears attached solidarizes with one of the articulated bars 1,2 or 3 .

Variant 1 (Fig. 4a) is obtained when wheel 2 is integral with rod 2 of length $\mathrm{AB}=12$ and gear wheel 4 has a fixed rotation axis in $\mathrm{B} 0$ being a driven wheel.

Because the toothed wheel 4 is a distinct kinematic element, equivalent to a zero mobility chain diadem, by adding it to the articulated quadrant $(0,1,2,3)$ and $\mathrm{A}_{0} \mathrm{ABB}_{0}$ respectively, the mechanism mobility is preserved.

For verification, mobility is calculated with the general formula (1), where the numerical values specific to this complex mechanism are introduced (Fig. 4a), (14-15).

Variant 2 (Fig. 4b) has two cylindrical gears mounted on bars 2 and 3 , where wheel 1 with a center in $A$ is integral with crank 1 of length $A_{0} A=11$ and wheels 4 (4') and 5 are elements distinct cinemas, having centers in $\mathrm{B}$ and $\mathrm{B}_{0}$ respectively. The two toothed wheels 4 (4') and 5 are equivalent to two dyadic chains, which preserve the mobility of the quadrilateral mechanism $\mathrm{M}=1$.

Variant 3 (Fig. 4c) comprises three cylindrical gears mounted on bars 1, 2 and 3, wherein the toothed wheel 0 with the center in A0 is integral with the base of the quadrilateral. Wheels $4\left(4^{\prime}\right), 5\left(5^{\prime}\right)$ and 6 are distinct elements which equate to three dyadic chains so that $\mathrm{M}=$ 1 mobility is preserved.

Chain mechanisms with pentalaters can be made with one or more cylindrical gears attached to the articulated pedal (Fig. 5), in which, in order to obtain the mobility one $(\mathrm{M}=1)$, two conditions are introduced which aim at the solidarity of two wheels toothbrushes with distinct bars.

It is noted that from each of the above-mentioned variants, by attaching another rod of the articulated pentalater there are obtained two other variants of gears and gears, which means 9 distinct variants.

Variant 1 (Fig. 5a) is obtained by using two toothed wheels (with teeth numbers $z_{3}$ and $z_{0}$ ) having the centers in the $\mathrm{C}$ and $\mathrm{C}$ joints of the bar 4 and solidarized by the movable bar 3 and the fixed 0 respectively.

In this way, the engagement of the two wheels is equivalent to the introduction of an additional link between bars 3 and 0 , which is equivalent to a bar and two articulations whose mobility is -1 .

The mobility of the resultant mechanism (Fig. 5a) is that of the articulated pentalater $(M=2)$, to which is added the mobility of the inserted engagement connection (-1), i.e., $M=2-1=1$.

\section{Conclusion}

The rods and gears consist of at least one movable articulated bar and one of the cylindrical, tapered or hipoidal gears. Only gears with circular or straight toothed gears, in which the relative position of the rotation or translation axes does not change, shall be considered. The topological structure of the gears and gears is characterized by a kinematic chain with articulated bars and at least one kinematic chain with gears. The kinematic chain may be chain open (with a fixed rotation joint) or closed chain (with at least two fixed joints). The kinematic chain with gears is attached to the kinematic chain with bars so that at least two gear wheels have centers in the bars of the bars and some wheels may be integral with the bars. In practice, some of these gears with gears and gears are known as planetary gears with cylindrical, conical or hipoidal gears.

The gearing of these gears in these complex mechanisms is carried out in the form of series, parallel, or both parallel-series trains.

The system is made according to the articulated plan cinematic chain, which can be made as an open or closed kinematic chain.

\section{Acknowledgement}

This text was acknowledged and appreciated by Dr. Veturia CHIROIU Honorific member of Technical Sciences Academy of Romania (ASTR) PhD supervisor in Mechanical Engineering.

\section{Funding Information}

Research contract: 1-Research contract: Contract number 36-5-4D/1986 from 24IV1985, beneficiary CNST RO (Romanian National Center for Science and Technology) Improving dynamic mechanisms.

2-Contract research integration. 19-91-3 from 29.03.1991; Beneficiary: MIS; TOPIC: Research on designing mechanisms with bars, cams and gears, with application in industrial robots.

3-Contract research. GR 69/10.05.2007: NURC in 2762; theme 8: Dynamic analysis of mechanisms and manipulators with bars and gears.

4-Labor contract, no. 35/22.01.2013, the UPB, "Stand for reading performance parameters of kinematics and dynamic mechanisms, using inductive and incremental encoders, to a Mitsubishi Mechatronic System" "PN-IIIN-CI-2012-1-0389".

All these matters are copyrighted! Copyrights: 394qodGnhhtej, from 17-02-2010 13:42:18; 463vpstuCGsiy, from 20-03-2010 12:45:30; 631sqfsgqvutm, from 24-05-2010 16:15:22; 933CrDztEfqow, from 07-01-2011 13:37:52.

\section{Author's Contributions}

This section should state the contributions made by each author in the preparation, development and publication of this manuscript. 


\section{Ethics}

Authors should address any ethical issues that may arise after the publication of this manuscript.

\section{References}

Antonescu, P. and F. Petrescu, 1985. An analytical method of synthesis of cam mechanism and flat stick. Proceedings of the 4th International Symposium on Theory and Practice of Mechanisms, (TPM' 89), Bucharest.

Antonescu, P. and F. Petrescu, 1989. Contributions to kinetoplast dynamic analysis of distribution mechanisms. Bucharest.

Antonescu, P., M. Oprean and F. Petrescu, 1985a. Contributions to the synthesis of oscillating cam mechanism and oscillating flat stick. Proceedings of the 4th International Symposium on Theory and Practice of Mechanisms, (TPM' 85), Bucharest.

Antonescu, P., M. Oprean and F. Petrescu, 1985b. At the projection of the oscillate cams, there are mechanisms and distribution variables. Proceedings of the 5th Conference of Engines, Automobiles, Tractors and Agricultural Machines, (TAM' 58), IMotors and Cars, Brasov.

Antonescu, P., M. Oprean and F. Petrescu, 1986. Projection of the profile of the rotating camshaft acting on the oscillating plate with disengagement. Proceedings of the 3rd National Computer-aided Design Symposium in the field of Mechanisms and Machine Parts, (MMP' 86), Brasov.

Antonescu, P., M. Oprean and F. Petrescu, 1987. Dynamic analysis of the cam distribution mechanisms. Proceedings of the 7th National Symposium on Industrial Robots and Space Mechanisms, (RSM' 87), Bucharest.

Antonescu, P., M. Oprean and F. Petrescu, 1988. Analytical synthesis of Kurz profile, rotating the flat cam. Mach, Build. Rev.

Antonescu, P., F. Petrescu and O. Antonescu, 1994. Contributions to the synthesis of the rotating cam mechanism and the tip of the balancing tip. Brasov.

Antonescu, P., F. Petrescu and D. Antonescu, 1997. Geometrical synthesis of the rotary cam and balance tappet mechanism. Bucharest, 3: 23-23.

Antonescu, P., F. Petrescu and O. Antonescu, 2000a. Contributions to the synthesis of the rotary disc-cam profile. Proceedings of the 8th International Conference on the Theory of Machines and Mechanisms, (TMM' 00), Liberec, Czech Republic, pp: 51-56.

Antonescu, P., F. Petrescu and O. Antonescu, 2000b. Synthesis of the rotary cam profile with balance follower. Proceedings of the 8th Symposium on Mechanisms and Mechanical Transmissions, (MMT’00), Timişoara, pp: 39-44.
Antonescu, P., F. Petrescu and O. Antonescu, 2001. Contributions to the synthesis of mechanisms with rotary disc-cam. Proceedings of the 8th IFToMM International Symposium on Theory of Machines and Mechanisms, (TMM' 01), Bucharest, ROMANIA, pp: 31-36.

Aversa, R., R.V.V. Petrescu, A. Apicella and F.I.T. Petrescu, 2017a. Nano-diamond hybrid materials for structural biomedical application. Am. J. Biochem. Biotechnol., 13: 34-41. DOI: 10.3844/ajbbsp.2017.34.41

Aversa, R., R.V. Petrescu, B. Akash, R.B. Bucinell and J.M. Corchado et al., 2017b. Kinematics and forces to a new model forging manipulator. Am. J. Applied Sci., 14: 60-80. DOI: 10.3844/ajassp.2017.60.80

Aversa, R., R.V. Petrescu, A. Apicella, F.I.T. Petrescu and J.K. Calautit et al., 2017c. Something about the $\mathrm{V}$ engines design. Am. J. Applied Sci., 14: 34-52. DOI: 10.3844/ajassp.2017.34.52

Aversa, R., D. Parcesepe, R.V.V. Petrescu, F. Berto and G. Chen et al., 2017d. Process ability of bulk metallic glasses. Am. J. Applied Sci., 14: 294-301. DOI: 10.3844/ajassp.2017.294.301

Aversa, R., R.V.V. Petrescu, B. Akash, R.B. Bucinell and J.M. Corchado et al., 2017e. Something about the balancing of thermal motors. Am. J. Eng. Applied Sci., 10: 200.217. DOI: 10.3844/ajeassp.2017.200.217

Aversa, R., F.I.T. Petrescu, R.V. Petrescu and A. Apicella, 2016a. Biomimetic FEA bone modeling for customized hybrid biological prostheses development. Am. J. Applied Sci., 13: 1060-1067. DOI: 10.3844/ajassp.2016.1060.1067

Aversa, R., D. Parcesepe, R.V. Petrescu, G. Chen and F.I.T. Petrescu et al., 2016b. Glassy amorphous metal injection molded induced morphological defects. Am. J. Applied Sci., 13: 1476-1482. DOI: 10.3844 /ajassp.2016.1476.1482

Aversa, R., R.V. Petrescu, F.I.T. Petrescu and A. Apicella, 2016c. Smart-factory: Optimization and process control of composite centrifuged pipes. Am. J. Applied Sci., 13: 1330-1341. DOI: 10.3844/ajassp.2016.1330.1341

Aversa, R., F. Tamburrino, R.V. Petrescu, F.I.T. Petrescu and M. Artur et al., 2016d. Biomechanically inspired shape memory effect machines driven by muscle like acting NiTi alloys. Am. J. Applied Sci., 13: 1264-1271. DOI: 10.3844/ajassp.2016.1264.1271

Aversa, R., E.M. Buzea, R.V. Petrescu, A. Apicella and M. Neacsa et al., 2016e. Present a mechatronic system having able to determine the concentration of carotenoids. Am. J. Eng. Applied Sci., 9: 1106-1111. DOI: 10.3844/ajeassp.2016.1106.1111

Aversa, R., R.V. Petrescu, R. Sorrentino, F.I.T. Petrescu and A. Apicella, 2016f. Hybrid ceramo-polymeric nanocomposite for biomimetic scaffolds design and preparation. Am. J. Eng. Applied Sci., 9: 1096-1105. DOI: 10.3844/ajeassp.2016.1096.1105 
Aversa, R., V. Perrotta, R.V. Petrescu, C. Misiano and F.I.T. Petrescu et al., 2016g. From structural colors to super-hydrophobicity and achromatic transparent protective coatings: Ion plating plasma assisted $\mathrm{TiO}_{2}$ and $\mathrm{SiO}_{2}$ nano-film deposition. Am. J. Eng. Applied Sci., 9: 1037-1045.

DOI: 10.3844/ajeassp.2016.1037.1045

Aversa, R., R.V. Petrescu, F.I.T. Petrescu and A. Apicella, 2016h. Biomimetic and evolutionary design driven innovation in sustainable products development. Am. J. Eng. Applied Sci., 9: 1027-1036. DOI: 10.3844/ajeassp.2016.1027.1036

Aversa, R., R.V. Petrescu, A. Apicella and F.I.T. Petrescu, 2016i. Mitochondria are naturally micro robots - a review. Am. J. Eng. Applied Sci., 9: 991-1002.

DOI: 10.3844/ajeassp.2016.991.1002

Aversa, R., R.V. Petrescu, A. Apicella and F.I.T. Petrescu, 2016j. We are addicted to vitamins $\mathrm{C}$ and EA review. Am. J. Eng. Applied Sci., 9: 1003-1018. DOI: 10.3844/ajeassp.2016.1003.1018

Aversa, R., R.V. Petrescu, A. Apicella and F.I.T. Petrescu, 2016k. Physiologic human fluids and swelling behavior of hydrophilic biocompatible hybrid ceramo-polymeric materials. Am. J. Eng. Applied Sci., 9: 962-972.

DOI: 10.3844 /ajeassp.2016.962.972

Aversa, R., R.V. Petrescu, A. Apicella and F.I.T. Petrescu, 20161. One can slow down the aging through antioxidants. Am. J. Eng. Applied Sci., 9: 1112-1126. DOI: 10.3844/ajeassp.2016.1112.1126

Aversa, R., R.V. Petrescu, A. Apicella and F.I.T. Petrescu, 2016m. About homeopathy or «Similia Similibus Curentur 》. Am. J. Eng. Applied Sci., 9: 1164-1172. DOI: 10.3844/ajeassp.2016.1164.1172

Aversa, R., R.V. Petrescu, A. Apicella and F.I.T. Petrescu, 2016n. The basic elements of life's. Am. J. Eng. Applied Sci., 9: 1189-1197. DOI: 10.3844/ajeassp.2016.1189.1197

Aversa, R., F.I.T. Petrescu, R.V. Petrescu and A. Apicella, 2016o. Flexible stem trabecular prostheses. Am. J. Eng. Applied Sci., 9: 1213-1221. DOI: 10.3844/ajeassp.2016.1213.122

Berto, F., R.V.V. Petrescu and F.I.T. Petrescu, 2016a. A review of recent results on $3 \mathrm{D}$ effects. Am. J. Eng. Applied Sci., 9: 1247-1260.

DOI: $10.3844 /$ ajeassp.2016.1247.1260

Berto, F., R.V.V. Petrescu and F.I.T. Petrescu, $2016 \mathrm{~b}$. Three-dimensional in bonded joints: A short review. Am. J. Eng. Applied Sci., 9: 1261-1268. DOI: $10.3844 /$ ajeassp.2016.1261.1268

Berto, F., A. Gagani, R.V.V. Petrescu and F.I.T. Petrescu, 2016c. Key-hole notches in isostatic graphite: A review of some recent data. Am. J. Eng. Applied Sci., 9: 1292-1300.

DOI: $10.3844 /$ ajeassp.2016.1292.1300
Berto, F., A. Gagani, R. Aversa, R.V.V. Petrescu and A. Apicella et al., 2016d. Multiaxial fatigue strength to notched specimens made of 40CrMoV13.9. Am. J. Eng. Applied Sci., 9: 1269-1291.

DOI: 10.3844/ajeassp.2016.1269.1291

Cao, W., H. Ding, Z. Bin and C. Ziming, 2013. New structural representation and digital-analysis platform for symmetrical parallel mechanisms. Int. J. Adv. Robotic Sys. DOI: 10.5772/56380

Comanescu, A., 2010. Bazele Modelarii Mecanismelor. 1st Edn., E. Politeh, Press, Bucureşti, pp: 274.

Dong, H., N. Giakoumidis, N. Figueroa and N. Mavridis, 2013. Approaching behaviour monitor and vibration indication in developing a General Moving Object Alarm System (GMOAS). Int. J. Adv. Robotic Sys. DOI: $10.5772 / 56586$

Franklin, D.J., 1930. Ingenious Mechanisms for Designers and Inventors. 1st Edn., Industrial Press Publisher.

He, B., Z. Wang, Q. Li, H. Xie and R. Shen, 2013. An analytic method for the kinematics and dynamics of a multiple-backbone continuum robot. IJARS. DOI: $10.5772 / 54051$

Lee, B.J., 2013. Geometrical derivation of differential kinematics to calibrate model parameters of flexible manipulator. Int. J. Adv. Robotic Sys. DOI: $10.5772 / 55592$

Lin, W., B. Li, X. Yang and D. Zhang, 2013. Modelling and control of inverse dynamics for a 5-DOF parallel kinematic polishing machine. Int. J. Adv. Robotic Sys. DOI: 10.5772/54966

Liu, H., W. Zhou, X. Lai and S. Zhu, 2013. An efficient inverse kinematic algorithm for a PUMA560structured robot manipulator. IJARS. DOI: $10.5772 / 56403$

Mirsayar, M.M., V.A. Joneidi, R.V.V. Petrescu, F.I.T. Petrescu and F. Berto, 2017. Extended MTSN criterion for fracture analysis of soda lime glass. Eng. Fracture Mechan., 178: 50-59.

DOI: 10.1016/j.engfracmech.2017.04.018

Padula, F. and V. Perdereau, 2013. An on-line path planner for industrial manipulators. Int. J. Adv. Robotic Sys. DOI: 10.5772/55063

Perumaal, S. and N. Jawahar, 2013. Automated trajectory planner of industrial robot for pick-andplace task. IJARS. DOI: 10.5772/53940

Petrescu, F. and R. Petrescu, 1995a. Contributions to optimization of the polynomial motion laws of the stick from the internal combustion engine distribution mechanism. Bucharest, 1: 249-256.

Petrescu, F. and R. Petrescu, 1995b. Contributions to the synthesis of internal combustion engine distribution mechanisms. Bucharest, 1: 257-264.

Petrescu, F. and R. Petrescu, 1997a. Dynamics of cam mechanisms (exemplified on the classic distribution mechanism). Bucharest, 3: 353-358. 
Petrescu, F. and R. Petrescu, 1997b. Contributions to the synthesis of the distribution mechanisms of internal combustion engines with a Cartesian coordinate method. Bucharest, 3: 359-364.

Petrescu, F. and R. Petrescu, 1997c. Contributions to maximizing polynomial laws for the active stroke of the distribution mechanism from internal combustion engines. Bucharest, 3: 365-370.

Petrescu, F. and R. Petrescu, 2000a. Synthesis of distribution mechanisms by the rectangular (Cartesian) coordinate method. Proceedings of the 8th National Conference on International Participation, (CIP' 00), Craiova, Romania, pp: 297-302.

Petrescu, F. and R. Petrescu, 2000b. The design (synthesis) of cams using the polar coordinate method (triangle method). Proceedings of the 8th National Conference on International Participation, (CIP' 00), Craiova, Romania, pp: 291-296.

Petrescu, F. and R. Petrescu, 2002a. Motion laws for cams. Proceedings of the International Computer Assisted Design, National Symposium with Participation, (SNP' 02), Braşov, pp: 321-326.

Petrescu, F. and R. Petrescu, 2002b. Camshaft dynamics elements. Proceedings of the International Computer Assisted Design, National Participation Symposium, (SNP' 02), Braşov, pp: 327-332.

Petrescu, F. and R. Petrescu, 2003. Some elements regarding the improvement of the engine design. Proceedings of the National Symposium, Descriptive Geometry, Technical Graphics and Design, (GTD' 03), Braşov, pp: 353-358.

Petrescu, F. and R. Petrescu, 2005a. The cam design for a better efficiency. Proceedings of the International Conference on Engineering Graphics and Design, (EGD' 05), Bucharest, pp: 245-248.

Petrescu, F. and R. Petrescu, 2005b. Contributions at the dynamics of cams. Proceedings of the 9th IFToMM International Symposium on Theory of Machines and Mechanisms, (TMM' 05), Bucharest, Romania, pp: 123-128.

Petrescu, F. and R. Petrescu, 2005c. Determining the dynamic efficiency of cams. Proceedings of the 9th IFToMM International Symposium on Theory of Machines and Mechanisms, (TMM' 05), Bucharest, Romania, pp: 129-134.

Petrescu, F. and R. Petrescu, 2005d. An original internal combustion engine. Proceedings of the 9th IFToMM International Symposium on Theory of Machines and Mechanisms, (TMM' 05), Bucharest, Romania, pp: 135-140.

Petrescu, F. and R. Petrescu, 2005e. Determining the mechanical efficiency of Otto engine's mechanism. Proceedings of the 9th IFToMM International Symposium on Theory of Machines and Mechanisms, (TMM 05), Bucharest, Romania, pp: 141-146.
Petrescu, F.I. and R.V. Petrescu, 2011a. Mechanical Systems, Serial and Parallel (Romanian). 1st Edn., LULU Publisher, London, UK, pp: 124.

Petrescu, FIT., Petrescu, RV., 2011b. Trenuri Planetare. Createspace Independent Pub., 104 pages, ISBN-13: 978-1468030419.

Petrescu, F.I. and R.V. Petrescu, 2012a. Kinematics of the planar quadrilateral mechanism. ENGEVISTA, 14: 345-348.

Petrescu, F.I. and R.V. Petrescu, 2012b. MecatronicaSisteme Seriale si Paralele. 1st Edn., Create Space Publisher, USA, pp: 128.

Petrescu, F.I. and R.V. Petrescu, 2013a. Cinematics of the 3R dyad. ENGEVISTA, 15: 118-124.

Petrescu, F.I. and R.V. Petrescu, 2013b. Forces and efficiency of cams. Int. Rev. Mechanical Eng.

Petrescu, F.I. and R.V. Petrescu, 2016a. Parallel moving mechanical systems kinematics. ENGEVISTA, 18: 455-491.

Petrescu, F.I. and R.V. Petrescu, 2016b. Direct and inverse kinematics to the anthropomorphic robots. ENGEVISTA, 18: 109-124.

Petrescu, F.I. and R.V. Petrescu, 2016c. Dynamic cinematic to a structure 2R. Revista Geintec-Gestao Inovacao E Tecnol., 6: 3143-3154.

Petrescu, R.V., R. Aversa, A. Apicella and F.I. Petrescu, 2016. Future medicine services robotics. Am. J. Eng. Applied Sci., 9: 1062-1087. DOI: 10.3844/ajeassp.2016.1062.1087

Petrescu, F.I., B. Grecu, A. Comanescu and R.V. Petrescu, 2009. Some mechanical design elements. Proceeding of the International Conference on Computational Mechanics and Virtual Engineering, (MVE' 09), Braşov, pp: 520-525.

Petrescu, F.I., 2011. Teoria Mecanismelor si a Masinilor: Curs Si Aplicatii. 1st Edn., CreateSpace Independent Publishing Platform. ISBN-10: 1468015826. pp: 432.

Petrescu, F.I.T., 2015a. Geometrical synthesis of the distribution mechanisms. Am. J. Eng. Applied Sci., 8: 63-81. DOI: 10.3844/ajeassp.2015.63.81

Petrescu, F.I.T., 2015b. Machine motion equations at the internal combustion heat engines. Am. J. Eng. Applied Sci., 8: 127-137.

DOI: 10.3844/ajeassp.2015.127.137

Petrescu, R.V., R. Aversa, B. Akash, R. Bucinell and J. Corchado et al., 2017a. Yield at thermal engines internal combustion. Am. J. Eng. Applied Sci., 10: 243-251. DOI: 10.3844/ajeassp.2017.243.251

Petrescu, R.V., R. Aversa, B. Akash, B. Ronald and J. Corchado et al., 2017b. Velocities and accelerations at the $3 \mathrm{R}$ mechatronic systems. Am. J. Eng. Applied Sci., 10: 252-263.

DOI: 10.3844 /ajeassp.2017.252.263 
Petrescu, R.V., R. Aversa, B. Akash, R. Bucinell and J. Corchado et al., 2017c. Anthropomorphic solid structures n-r kinematics. Am. J. Eng. Applied Sci., 10: 279-291. DOI: 10.3844/ajeassp.2017.279.291

Petrescu, R.V., R. Aversa, B. Akash, R. Bucinell and J. Corchado et al., 2017d. Inverse kinematics at the anthropomorphic robots, by a trigonometric method. Am. J. Eng. Applied Sci., 10: 394-411.

DOI: 10.3844 /ajeassp.2017.394.411

Petrescu, R.V., R. Aversa, B. Akash, R. Bucinell and J. Corchado et al., 2017e. Forces at internal combustion engines. Am. J. Eng. Applied Sci., 10: 382-393. DOI: 10.3844/ajeassp.2017.382.393

Petrescu, R.V., R. Aversa, B. Akash, R. Bucinell and J. Corchado et al., 2017f. Gears-Part I. Am. J. Eng. Applied Sci., 10: 457-472.

DOI: 10.3844/ajeassp.2017.457.472

Petrescu, R.V., R. Aversa, B. Akash, R. Bucinell and J. Corchado et al., 2017g. Gears-part II. Am. J. Eng. Applied Sci., 10: 473-483.

DOI: 10.3844/ajeassp.2017.473.483

Petrescu, R.V., R. Aversa, B. Akash, R. Bucinell and J. Corchado et al., 2017h. Cam-gears forces, velocities, powers and efficiency. Am. J. Eng. Applied Sci., 10: 491-505. DOI: 10.3844/ajeassp.2017.491.505

Petrescu, R.V., R. Aversa, B. Akash, R. Bucinell and J. Corchado et al., 2017i. Dynamics of mechanisms with cams illustrated in the classical distribution. Am. J. Eng. Applied Sci., 10: 551-567. DOI: 10.3844 /ajeassp.2017.551.567

Petrescu, R.V., R. Aversa, B. Akash, R. Bucinell and J. Corchado et al., 2017j. Testing by non-destructive control. Am. J. Eng. Applied Sci., 10: 568-583. DOI: 10.3844/ajeassp.2017.568.583

Petrescu, R.V., R. Aversa, A. Apicella and F.I.T. Petrescu, 2017k. Transportation engineering. Am. J. Eng. Applied Sci., 10: 685-702.

DOI: 10.3844/ajeassp.2017.685.702

Petrescu, R.V., R. Aversa, S. Kozaitis, A. Apicella and F.I.T. Petrescu, 20171. The quality of transport and environmental protection, part I. Am. J. Eng. Applied Sci., 10: 738-755. DOI: 10.3844/ajeassp.2017.738.755

Petrescu, R.V., R. Aversa, B. Akash, R. Bucinell and J. Corchado et al., $2017 \mathrm{~m}$. Modern propulsions for aerospace-a review. J. Aircraft Spacecraft Technol., 1: 1-8. DOI: 10.3844/jastsp.2017.1.8

Petrescu, R.V., R. Aversa, B. Akash, R. Bucinell and J. Corchado et al., 2017n. Modern propulsions for aerospace-part II. J. Aircraft Spacecraft Technol., 1: 9-17. DOI: $10.3844 /$ jastsp.2017.9.17

Petrescu, R.V., R. Aversa, B. Akash, R. Bucinell and J. Corchado et al., 2017o. History of aviation-a short review. J. Aircraft Spacecraft Technol., 1: 30-49. DOI: 10.3844 jastsp.2017.30.49
Petrescu, R.V., R. Aversa, B. Akash, R. Bucinell and J. Corchado et al., 2017p. Lockheed martin-a short review. J. Aircraft Spacecraft Technol., 1: 50-68. DOI: 10.3844 jastsp.2017.50.68

Petrescu, R.V., R. Aversa, B. Akash, J. Corchado and F. Berto et al., 2017q. Our universe. J. Aircraft Spacecraft Technol., 1: 69-79. DOI: 10.3844/jastsp.2017.69.79

Petrescu, R.V., R. Aversa, B. Akash, J. Corchado and F. Berto et al., 2017r. What is a UFO? J. Aircraft Spacecraft Technol., 1: 80-90. DOI: $10.3844 /$ jastsp.2017.80.90

Petrescu, R.V., R. Aversa, B. Akash, J. Corchado and F. Berto et al., 2017s. About bell helicopter FCX-001 concept aircraft-a short review. J. Aircraft Spacecraft Technol., 1: 91-96. DOI: 10.3844/jastsp.2017.91.96

Petrescu, R.V., R. Aversa, B. Akash, J. Corchado and F. Berto et al., 2017t. Home at airbus. J. Aircraft Spacecraft Technol., 1: 97-118. DOI: $10.3844 /$ jastsp.2017.97.118

Petrescu, R.V., R. Aversa, B. Akash, J. Corchado and F. Berto et al., 2017u. Airlander. J. Aircraft Spacecraft Technol., 1: 119-148. DOI: $10.3844 /$ jastsp.2017.119.148

Petrescu, R.V., R. Aversa, B. Akash, J. Corchado and F. Berto et al., 2017v. When boeing is dreaming-a review. J. Aircraft Spacecraft Technol., 1: 149-161. DOI: 10.3844 /jastsp.2017.149.161

Petrescu, R.V., R. Aversa, B. Akash, J. Corchado and F. Berto et al., 2017w. About Northrop Grumman. J. Aircraft Spacecraft Technol., 1: 162-185. DOI: $10.3844 /$ jastsp.2017.162.185

Petrescu, R.V., R. Aversa, B. Akash, J. Corchado and F. Berto et al., 2017x. Some special aircraft. J. Aircraft Spacecraft Technol., 1: 186-203. DOI: 10.3844/jastsp.2017.186.203

Petrescu, R.V., R. Aversa, B. Akash, J. Corchado and F. Berto et al., 2017y. About helicopters. J. Aircraft Spacecraft Technol., 1: 204-223. DOI: 10.3844/jastsp.2017.204.223

Petrescu, R.V., R. Aversa, B. Akash, F. Berto and A. Apicella et al., 2017z. The modern flight. J. Aircraft Spacecraft Technol., 1: 224-233. DOI: 10.3844/jastsp.2017.224.233

Petrescu, R.V., R. Aversa, B. Akash, F. Berto and A. Apicella et al., 2017aa. Sustainable energy for aerospace vessels. J. Aircraft Spacecraft Technol., 1: 234-240. DOI: 10.3844/jastsp.2017.234.240

Petrescu, R.V., R. Aversa, B. Akash, F. Berto and A. Apicella et al., 2017ab. Unmanned helicopters. J. Aircraft Spacecraft Technol., 1: 241-248. DOI: $10.3844 /$ jastsp.2017.241.248

Petrescu, R.V., R. Aversa, B. Akash, F. Berto and A. Apicella et al., 2017ac. Project HARP. J. Aircraft Spacecraft Technol., 1: 249-257. DOI: $10.3844 /$ jastsp.2017.249.257 
Petrescu, R.V., R. Aversa, B. Akash, F. Berto and A. Apicella et al., 2017ad. Presentation of Romanian engineers who contributed to the development of global aeronautics-part I. J. Aircraft Spacecraft Technol., 1: 258-271. DOI: 10.3844 /jastsp.2017.258.271

Petrescu, R.V., R. Aversa, B. Akash, F. Berto and A. Apicella et al., 2017ae. A first-class ticket to the planet mars, please. J. Aircraft Spacecraft Technol., 1: 272-281. DOI: 10.3844/jastsp.2017.272.281

Petrescu, R.V., R. Aversa, A. Apicella, M.M. Mirsayar and S. Kozaitis et al., 2018a. NASA started a propeller set on board voyager 1 after 37 years of break. Am. J. Eng. Applied Sci., 11: 66-77.

DOI: 10.3844/ajeassp.2018.66.77

Petrescu, R.V., R. Aversa, A. Apicella, M.M. Mirsayar and S. Kozaitis et al., 2018b. There is life on mars? Am. J. Eng. Applied Sci., 11: 78-91. DOI: 10.3844/ajeassp.2018.78.91

Petrescu, R.V., R. Aversa, A. Apicella and F.I.T. Petrescu, 2018c. Friendly environmental transport. Am. J. Eng. Applied Sci., 11: 154-165. DOI: 10.3844/ajeassp.2018.154.165

Petrescu, R.V., R. Aversa, B. Akash, T.M. Abu-Lebdeh and A. Apicella et al., 2018d. Buses running on gas. Am. J. Eng. Applied Sci., 11: 186-201. DOI: 10.3844/ajeassp.2018.186.201

Petrescu, R.V., R. Aversa, B. Akash, T.M. Abu-Lebdeh and A. Apicella et al., 2018e. Some aspects of the structure of planar mechanisms. Am. J. Eng. Applied Sci., 11: 245-259.

DOI: 10.3844/ajeassp.2018.245.259

Petrescu, RV., R. Aversa, T.M. Abu-Lebdeh, A. Apicella and F.I.T. Petrescu, 2018f. The forces of a simple carrier manipulator. Am. J. Eng. Applied Sci., 11: 260-272. DOI: 10.3844/ajeassp.2018.260.272

Petrescu, RV., R. Aversa, T.M. Abu-Lebdeh, A. Apicella and F.I.T. Petrescu, 2018g. The dynamics of the otto engine. Am. J. Eng. Applied Sci., 11: 273-287.

DOI: 10.3844 /ajeassp.2018.273.287
Petrescu, RV., R. Aversa, T.M. Abu-Lebdeh, A. Apicella and F.I.T. Petrescu, 2018h. NASA satellites help us to quickly detect forest fires. Am. J. Eng. Applied Sci., 11: 288-296.

DOI: 10.3844 /ajeassp.2018.288.296

Petrescu, RV., R. Aversa, T.M. Abu-Lebdeh, A. Apicella and F.I.T. Petrescu, 2018i. Kinematics of a mechanism with a triad. Am. J. Eng. Applied Sci., 11: 297-308. DOI: 10.3844/ajeassp.2018.297.308

Petrescu, R.V., R. Aversa, A. Apicella and F.I.T. Petrescu, 2018j. Romanian engineering "on the wings of the wind". J. Aircraft Spacecraft Technol., 2: 1-18. DOI: $10.3844 /$ jastsp.2018.1.18

Petrescu, R.V., R. Aversa, A. Apicella and F.I.T. Petrescu, 2018k. NASA Data used to discover eighth planet circling distant star. J. Aircraft Spacecraft Technol., 2: 19-30. DOI: $10.3844 /$ jastsp.2018.19.30

Petrescu, R.V., R. Aversa, A. Apicella and F.I.T. Petrescu, 20181. NASA has found the most distant black hole. J. Aircraft Spacecraft Technol., 2: 31-39. DOI: $10.3844 /$ jastsp.2018.31.39

Petrescu, R.V., R. Aversa, A. Apicella and F.I.T. Petrescu, 2018m. Nasa selects concepts for a new mission to titan, the moon of saturn. J. Aircraft Spacecraft Technol., 2: 40-52. DOI: $10.3844 /$ jastsp.2018.40.52

Petrescu, R.V., R. Aversa, A. Apicella and F.I.T. Petrescu, 2018n. NASA sees first in 2018 the direct proof of ozone hole recovery. J. Aircraft Spacecraft Technol., 2: 53-64. DOI: 10.3844/jastsp.2018.53.64

\section{Source of Figures:}

Petrescu and Petrescu, $2011 \mathrm{~b}$. 